\title{
Characterization of Sclerotinia sclerotiorum, an Emerging Fungal Pathogen Causing Blight in Hyacinth Bean (Lablab purpureus)
}

\author{
Ananya Prova ${ }^{1}$, Abdul Mannan Akanda ${ }^{2}$, Shaikhul Islam ${ }^{2}$, and Md. Motaher Hossain ${ }^{2 *}$ \\ ${ }^{I}$ Department of Plant Pathology, EXIM Bank Agricultural University, Chapainawabganj-6300, Bangladesh \\ ${ }^{2}$ Department of Plant Pathology, Bangabandhu Sheikh Mujibur Rahman Agricultural University, Gazipur-1706, Ban- \\ gladesh
}

(Received on March 11, 2018; Revised on July 17, 2018; Accepted on July 22, 2018)

Stems and pods of hyacinth bean cultivated in a farmer's field in Gazipur District, Bangladesh, were found rotted in nearly $5 \%$ hyacinth bean plants. A fungus having fluffy mycelium and large sclerotia was isolated from affected tissues. Combined results of morphological, molecular and pathological analyses identified the fungus as Sclerotinia sclerotiorum (Lib) de Bary. Inoculating the fungus on healthy hyacinth bean plants and pods reproduced the symptoms previously observed in the field. The three isolates obtained from naturally infected plants were cross inoculated in hyacinth bean, okra and African-American marigold and they were pathogenic to these hosts. The optimum temperature and $\mathrm{pH}$ for its growth were $20^{\circ} \mathrm{C}$ and $\mathrm{pH}$ 5.0, respectively. Sclerotial development was favored at pH 5.0. Sucrose and mannitol were the best carbon sources to support hyphal growth, while glucose was the most favourable for sclerotial development. The hyacinth bean genotypes, HB-82 (Rupban Sheem) and HB-102 were found highly resistant, while HB-94 (Ashina) was moderate resistant to the fungus. Finally, S. sclerotiorum was sensitive to Bavistin, Dithane M-45 and Rovral fungicides and $\mathrm{Ca}$ in the form of $\mathrm{CaCl}_{2}$. This observation could possibly aid in eliminating field loss in hyacinth bean caused by an emerging pathogenic fungus $S$. sclerotiorum.

\footnotetext{
*Corresponding author.

Phone) +88-02-9205310, FAX) +88-02-9205316

E-mail) hossainmm@bsmrau.edu.bd

(c) This is an Open Access article distributed under the terms of the Creative Commons Attribution Non-Commercial License (http:// creativecommons.org/licenses/by-nc/4.0) which permits unrestricted noncommercial use, distribution, and reproduction in any medium, provided the original work is properly cited.
}

Articles can be freely viewed online at www.ppjonline.org.
Keywords : Fungicides, host resistance, mycelial growth, new pathogen, sclerotial development

Handling Associate Editor : Lee, Jungkwan

Hyacinth bean (Lablab purpureus) is one of the most important winter vegetables in Bangladesh. It is very nutritious as the young pods and seeds are used as cooked food. The green pod contains nearly $5 \%$ protein, $0.1 \%$ fat, and $10 \%$ carbohydrate, while the pulse contains around $25 \%$ protein, $0.8 \%$ fat, and $60 \%$ carbohydrate (National Research Council, 2006). It is widely cultivated in the country, planting approximately 17,000 ha across the country during the winter season and yielding an average of 5.89 tons of fresh pods per ha (Bangladesh Bureau of Statistics, 2014). Hyacinth bean is extremely susceptible to diseases and pests and a major share of the production is expected to be lost every year (Hatcher and Paul, 2001; Schwartz and Poster, 1989). There are number of distinct fungal, bacterial and viral diseases commonly encountered by hyacinth bean plants. These diseases are the major reasons behind the low level of hyacinth bean production in Bangladesh.

Recently, in 2012, a significant damage of stem and pod rot was observed in hyacinth bean fields in Gazipur District, Bangladesh. Infected stems and pods showed both internal and external large brown areas with necrotic tissues. The fungus was also observed to infect leaves. Fluffy white mycelia were evident on infected tissues. Some infected plant parts died prematurely and became bleached. Black sclerotia formed on the surface of infected tissues or were embedded within tissues. A sclerotiumforming fungus was isolated from all samples of diseases of hyacinth bean plants. Preliminary studies in cultural characteristics, size of sclerotia and pathogenicity showed 
that the sclerotium-forming fungus belong to the species Sclerotinia sclerotiorum (Prova et al., 2014). The disease was observed in successive years with a significant lower yield. In all cases, sclerotia and fungi recovered from the affected tissue was confirmed as $S$. sclerotiorum. The Sclerotinia disease on hyacinth bean has previously been reported in India and elsewhere (Heffer and Johnson, 2007; Prajapati and Narain, 2008). The disease has had major impacts on hyacinth bean production, and significant efforts have been made to manage them. The disease seems to be an emerging and recurring problem in Bangladesh (Prova et al., 2014).

Sclerotinia disease of different host plants is a major problem worldwide and losses of up to $50 \%$ have been reported (Young et al., 2001). The fungus is a filamentous ascomycete phytopathogen infecting over 400 plant species (Kirk et al., 2001). The fungus is among the few fungal pathogens considered as typical necrotrophs. Consequently, they secrete an array of cell wall-degrading enzymes and toxins and derive energy to complete their life cycle mostly from dead plant cells, as opposed to biotrophs that feed on living plant cells (Amselem et al., 2011). Current studies have, however, showed that interactions between necrotrophs and their host plants are considerably more complex and subtle than previously appreciated. The necrotrophs secrete effector proteins which are adopted by host cells and interact with the host in a gene-for-gene relationship to initiate disease, although in an inverse manner compared to the biotrophs (Oliver and Solomon, 2010). In the case of $S$. sclerotiorum, the active modulation of the host redox status and the subversion of host programmed cell death pathways by the pathogen appear to be crucial for disease to develop (Williams et al., 2011). The accessibility of molecular tools has considerably advanced our understanding of the infection strategies and pathogenic development of $S$. sclerotiorum.

The ability of $S$. sclerotiorum to infect different plant species and tissues under a wide range of environmental conditions, as well as its ability to produce sclerotia that survive in the soil for many years, contribute to the persistent and widespread nature of this pathogen. Sclerotia play an important role in disease cycles by germinating either vegetatively for local colonization or carpogenically to initiate the sexual cycle including the production of apothecia from which ascospores are released (Bardin and Huang, 2001; Bolton et al., 2005). Under favorable conditions of cool and wet weather for an extended period, S. sclerotiorum invades host plants causing rot on plant parts. On the infected plant tissue the fungus firstly develops a characteristic fluffy white mycelium which later on gives rise to sclerotia, the most noticeable trait on infected plants. Temperature and $\mathrm{pH}$ value of substrate have been known to strongly influence mycelial growth, metabolite biosynthesis, cellular morphology and sclerotial development of the fungus (Rollins and Dickman, 2001). Similarly, nutrient sources such as carbon and nitrogen serve as significant factors in growth and sclerotial development (Shin et al., 2007). Hence, an understanding of the conditions for $S$. sclerotiorum inoculum production is required for successful management of the disease.

Achieving good control of Sclerotinia blight is difficult and a challenge in all crops. Management of the disease requires the use of a wide range of strategies. Fungicide application can decrease the disease incidence and increase the yield, on both susceptible and resistant cultivars (Woodward et al., 2015). Calcium salts also have been shown to reduce mycelial growth in vitro and reduce incidence and severity of infection by different pathogens (Biggs, 1999; Chardonnet et al., 1999). Similarly, host resistance to the disease may also greatly improve crop production in fields with a severe history of the disease. Since the disease is new to hyacinth bean in Bangladesh, data regarding the correct identification of the disease, effectiveness of potential fungicides against $S$. sclerotiorum and sources of resistance to the pathogen in hyacinth bean cultivars have been lacking. Therefore, the objectives of this study were to characterize the $S$. sclerotiorum causing stem and pod blight in hyacinth bean and develop a strategy for reducing the disease problem.

\section{Materials and Methods}

Detection and isolation of the pathogen. A total of 20 hyacinth bean fields in Gazipur districts of Bangladesh were surveyed for the presence of white mold (stem and pod blight) disease during February-March in 2012. Bean field was randomly selected. Depending on the size of the field, 5 to 10 sections of 10-20 ft row length were scouted. Sites were chosen throughout the field and the canopy were examined for symptoms of the disease. Ten infected stems and pods were collected from a farmer's field in Gazipur District. They were washed in tap water and dried on sterile blotter paper. Symptomatic pod tissues were cut into 2-3-mm pieces, surface-sterilized with $70 \%$ ethanol for $30 \mathrm{~s}$ and then with $0.1 \%$ mercuric chloride solution for $3 \mathrm{~min}$. After rinsing in sterile distilled water three times and subsequent drying on blotter paper, 30 tissue pieces were placed in Petri dishes containing potato dextrose agar (PDA) made from peeled potato infusion and amended with streptomycin sulphate $(1.0 \mathrm{~g} / 1)$. Petri dishes were 
incubated at $25^{\circ} \mathrm{C}$ in the dark for 5 days. This isolates were maintained on PDA slant at $4^{\circ} \mathrm{C}$.

Morphological characterization of the isolate. Morphological characteristics of the isolated fungal pathogens such as mycelial pattern, sclerotial characters, conidia, conidiophore, distinctive nature of apothecia, and ascospores were studied both at asexual and sexual stages for the identification of the pathogen. Single hyphal tips of each fungal isolate were transferred onto new PDA dishes and cultured for a week. Colony characteristics and sclerotial morphology of the fungus were studied with naked eye. Permanent slides were prepared from colony and examined under light microscope to observe the fungal structures at different magnification.

Morphological characteristics of the teleomorph stages of 20 isolates were examined. Surface-sterilized sclerotia were placed in $9 \mathrm{~cm}$ diameter Petri dishes filled with sterile, wet sand and incubated at $4^{\circ} \mathrm{C}$ for $5-6$ weeks. Then the Petri dishes containing germinating sclerotia were transferred to another incubator and illuminated for 3-4 days at $20^{\circ} \mathrm{C}$ under scattered fluorescent irradiation $(260$ $\mu \mathrm{mol} / \mathrm{m}^{2} / \mathrm{s}$ ) until apothecial discs were formed (Huang et al., 2005). Fifteen apothecia and the ascospores produced from sclerotia were examined under the microscope (40X and 100X) for morphological features.

Confirmation of the pathogenicity of the isolate. Pathogenicity of an isolate (PSHB1) was tested. The hyacinth bean variety 'BARI Sheem-1' was used throughout the study. The hyacinth bean seeds were surface sterilized and sown in circular earthen pots filled with sterile soil in the net house. When the seedlings were 4-week-old, PDA plugs excised from actively growing margins of fungal colonies were placed in wounds made in the stem bark approximately $10 \mathrm{~cm}$ above the soil line with a sterile blade and sealed with moistened cheese cloth. Wounded plants inoculated with sterile PDA plugs served as controls. The inoculated plants were subsequently covered with plastic bags and maintained in a growth chamber in dark for $48 \mathrm{~h}$ at $23-25^{\circ} \mathrm{C}$. The inoculated seedlings were then transferred to net house and grown until observation for 20 days. Twenty plants were inoculated with isolate PSHB1, and 20 plants were included as controls. Pathogenicity of the isolate was also tested on hyacinth bean pods and leaves by placing a mycelial plug of the fungus onto an incised pod and leaf surface in a similar manner. Re-isolation of the fungus was done from symptomatic tissues to compare and confirm that the original and the re-isolated fungus were the same.
Cross inoculation of hosts with different isolates. A second pathogenicity test was carried out where three host plant species were cross inoculated with the three pathogen isolates isolated from them. The test plants used were the hyacinth bean cultivar 'BARI Sheem-1', the okra cultivar BARI OKRA-1 and the African-American marigold (Boro Gada). These plants were inoculated 4 weeks after sowing. For the inoculation, one mycelium disc of the fungus (15 mm diameter) was taken from a 7 day-old fungus colony in PDA. The mycelium discs were attached to the crown region of the test plants as described above. Control test plants received only one PDA disc, attached to the crown by a sterilized cheese cloth. After inoculation, plants were kept in wet chambers for $48 \mathrm{~h}$ as described above. Subsequently, plants were kept in the net house during 20 days. The complete experiment consisted of three treatments with four replicates. Each replicate was represented by one pot with two plants, cultivated in sterilized soil. Evaluation was carried out 20 days after inoculation when the presence of characteristic symptoms of white mold and formation of sclerotia on the lesions was observed. After evaluation the pathogen was isolated in pure culture again.

Molecular identification. Total genomic DNA was extracted as described by Toda et al. (1999). Polymerase chain reaction (PCR) was conducted with forward primer ITS-1 (5'-TCC GTA GGT GAACCT GCG G-3') and reverse primer ITS-4 (5'-TCC TCC GCT TAT TGATAT GC-3') (White et al., 1990) to amplify rDNA-ITS regions of the fungal isolate PSHB1. PCR was done following the method described by Hayakawa et al. (2006). At least two complete sequences were obtained for each ITS region and the BLAST search program was used to search for nucleotide sequence homology in GenBank. Highly homologous sequences were aligned using Clustal- $X$ version 2.0.11 and manually adjusted as required. Neighbour joining trees were generated using MEGA version 6.06 (Hossain et al., 2014; Islam et al., 2016). Bootstrap replication (1000 replications) was used as a statistical support for the nodes in the phylogenetic trees. Based on maximum sequence homology percentage, query coverage, and the lowest $\mathrm{E}$ value, ITS sequence data of seventeen isolates of S. sclerotiorum were selected for phylogenetic analysis. Additionally, four isolates of each of $S$. minor and S. trifolium were included in this analysis, while Hypocrea lixii was used as an out group taxon (GenBank accession no. FJ 861393.1).

Effect of temperature and $\mathrm{pH}$ on mycelial growth and pH on formation of sclerotia of $S$. sclerotiorum. We further examined the growth properties of the Sclerotinia 
isolate by growing it on PDA at diverse temperature and narrow $\mathrm{pH}$ ranges. Mycelium plugs of $5 \mathrm{~mm}$ diameter were cut from a 7-day culture and placed on PDA in $9 \mathrm{~cm}$ diameter Petri plates and incubated at 5, 10, 15, 20, 25, and $30^{\circ} \mathrm{C}$ in the dark. Similarly, PDA media were prepared with a $\mathrm{pH}$ of 5.0 and 7.0. Mycelium plugs of $5 \mathrm{~mm}$ diameter were cut from a 7-day culture and placed in the centre of the new plates filled with $20 \mathrm{ml}$ of fixed pH PDA. The cultures were incubated at $20^{\circ} \mathrm{C}$ in dark with 10 replicates for each treatment. The radius of colonies was measured at 24, 48, 72 and $96 \mathrm{~h}$ after incubation. Cultures were monitored for sclerotial development and then number, diameter and weight of sclerotia were taken after 15 days. The experiment was repeated three times.

Effect of different carbon sources and $\mathrm{pH}$ values on mycelial growth and sclerotial formation of $S$. sclerotiorum. The growth properties of the $S$. sclerotiorum strain PSHB1 was examined by growing it on different culture media at diverse $\mathrm{pH}$ ranges (5.0, 7.0 and 10.0). The complete medium was composed of peptone at $4.0 \mathrm{~g} /$ 1, carbon sources (sucrose, mannitol, glucose, fructose or starch) at $20 \mathrm{~g} / \mathrm{l}, \mathrm{MgSO}_{4}$ at $0.5 \mathrm{~g} / 1, \mathrm{KH}_{2} \mathrm{SO}_{4}$ at $1.0 \mathrm{~g} / \mathrm{l}$, and agar at $20 \mathrm{~g} / \mathrm{l}$. The initial $\mathrm{pH}$ value was adjusted to 5.0, 7.0 and 10.0 prior to autoclaving and before starting the fungal culture. Mycelium plugs of $5 \mathrm{~mm}$ diameter were obtained from the edge of a 7-day culture of the fungus and placed to the centre of each $9 \mathrm{~cm}$ Petri plate containing $20 \mathrm{ml}$ solid agar media. The cultures were incubated at $20^{\circ} \mathrm{C}$ in dark with 10 replicates for each treatment. The mycelial growth was determined by measuring colony diameters at $96 \mathrm{~h}$ after incubation. The same cultures were left a few more days to induce the fungus to initiate sclerotial formation. After culture for 15 days, sclerotial weight was measured. The experiment was repeated three times.

Screening of hyacinth bean genotypes. Sixteenth hyacinth bean genotypes were collected from farmer's fields, local seed market, Genetic Resources Unit of Bangladesh Agricultural Research Institute, Gazipur, Bangladesh and Bangabandhu Sheikh Mujibur Rahman Agricultural University, Gazipur, Bangladesh (Table 1). The genotypes included both locally available common bean lines and released cultivars. They were screened against the isolated fungus using a detached leaf assay as described by Dong et al. (2008). Second true leaves were cut from 15 plants for each genotype and placed on wet paper towels in plastic boxes. Mycelial plug of $5 \mathrm{~mm}$ diameter excised from the edge of fresh culture of S. sclerotiorum was placed on one side of the main vein of each leaves. The inoculated leaves were kept in dark at $20^{\circ} \mathrm{C}$ for $48 \mathrm{~h}$. Then the inoculated leaves were transferred to a growth chamber under continuous fluorescent light at $20-22^{\circ} \mathrm{C}$. Every 24 $\mathrm{h}$, symptoms, including the sizes of the brown lesions and yellowing area surrounding the lesions, were measured in length and width. Additional leaves were mock inoculated with autoclaved PDA plugs as controls. Four days after pathogen challenge, disease severity was measured for each plant by recording the percentage of total plant leaf surface showing symptoms from $0=$ no symptoms to $4=$ most severe with necrotic symptoms. Disease severity obtained from each genotype was used to categorize individuals as highly resistant (HR), resistant (R), moderately resistant (MR), susceptible (S), or highly susceptible (HS). Entries with $\geq 75.0 \%$ disease severity were classified as HS, $\geq 50.0-74.9 \%$ as $\mathrm{S}, \geq 25.0-49.9 \%$ as $\mathrm{MR}, \geq 1.0-25.0 \%$ as $\mathrm{R}$ and $\geq 0.0-0.99 \%$ as HR.

In vitro bioassay of fungicides and calcium for their fungi toxicity on the radial growth of Sclerotinia sclerotiorum. Five available fungicides, namely Bavistin 50 WP (Carbendazim) (BASF Bangladesh Ltd., Dhaka, Bangladesh), Ridomil Gold MZ (Mefenoxam + Mancozeb), (Syngenta Bangladesh Ltd., Dhaka, Bangladesh), Dithane M-45 (Mancozeb) (Bayer CropScience Ltd., Dhaka, Bangladesh), Kumulus DF (Sulphur) (BASF Bangladesh Ltd., Dhaka, Bangladesh) and Rovral (Iprodione) (Bayer CropScience Ltd., Dhaka, Bangladesh) were tested against colony growth of $S$. sclerotiorum. The fungicides were chosen for the experiments since they are most widely used groups of fungicides in Bangladesh. Additionally, we checked the inhibitory effect of $\mathrm{CaCl}_{2}$ on radial growth of the fungus. Fungicides and $\mathrm{Ca}$ were added at a concentration of 10,50 , and $100 \mathrm{ppm}$ in an autoclaved PDA medium (Though they are very much soluble in PDA medium) following poisoned-food techniques (Akhter et al., 2015). The $\mathrm{pH}$ was adjusted before autoclaving as well as before starting the fungal growth. A $5 \mathrm{~mm}$ diameter agar disk of test fungi was cut from a 3-day-old culture and placed in the center of Petri plates containing different concentrations of fungicides. There were four replicates of each treatment. The plates without fungicides served as control. The inoculated plates were incubated at $20^{\circ} \mathrm{C}$. The radial growth was recorded after 7 days of incubation when the fungus in control plates covered the plates completely. The percent inhibition (PI) of the fungus over the control was calculated during the formula of Sundar et al. (1995).

$$
\% \text { Inhibition of growth }=\frac{X-Y}{X} \times 100
$$


Where,

$\mathrm{X}=$ Mycelial growth of the pathogen in absence of fungicides

$\mathrm{Y}=$ Mycelial growth of pathogen in presence of fungicides

Statistical analysis: The XL STAT (Version. 2012) and Microsoft Office Excel 2007 program package were used for statistical analysis. The experimental design was completely randomized, consisting of three replications for each treatment. The experiment was repeated at least twice and treatment means obtained were separated using a t-test or Fisher's LSD test $(\propto=0.05)$.

\section{Results}

Detection, isolation and characterization of the pathogen. In our study, the suspected disease was observed in all the 20 fields surveyed. In each field, nearly $5 \%$ plants showed suspected disease symptoms. Infected plants were at physiological maturity but had not senesced. Infected stems and pods showed both internal and external large brown areas with necrotic tissues. The fungus was also observed to infect leaves. Fluffy white mycelia were evident on infected tissues. Some infected plant parts died prematurely and became bleached. Black sclerotia formed on the surface of infected tissues or were embedded within tissues (Fig. 1A). On the infected plant tissues, the typical white mycelium and the resting bodies (sclerotia) were observed. The sclerotia were irregular in shape whose length ranged from 2.9 to $15.2 \mathrm{~mm}$ and wide ranged from 2.2 to $5.2 \mathrm{~mm}$. On PDA, colonies were fast growing with white, floccose, aerial mycelia and reverse salmonbuff color (Fig. 1B). Under microscope, the hyphae were hyaline, branched and multinucleate (Fig. 1C). No conidia or conidiophores were produced. Sclerotia developed in culture at the growing margins of the colonies, forming concentric rings and radiating lines (Fig. 1C). Sclerotia were variable in shape, but mostly globose to cylindrical with a black outer rind and a white inner cortex. Individual sclerotium was 2-7 mm long and 2-4 mm wide. The fungus produced 15 to 20 sclerotia per PDA Petri plate.
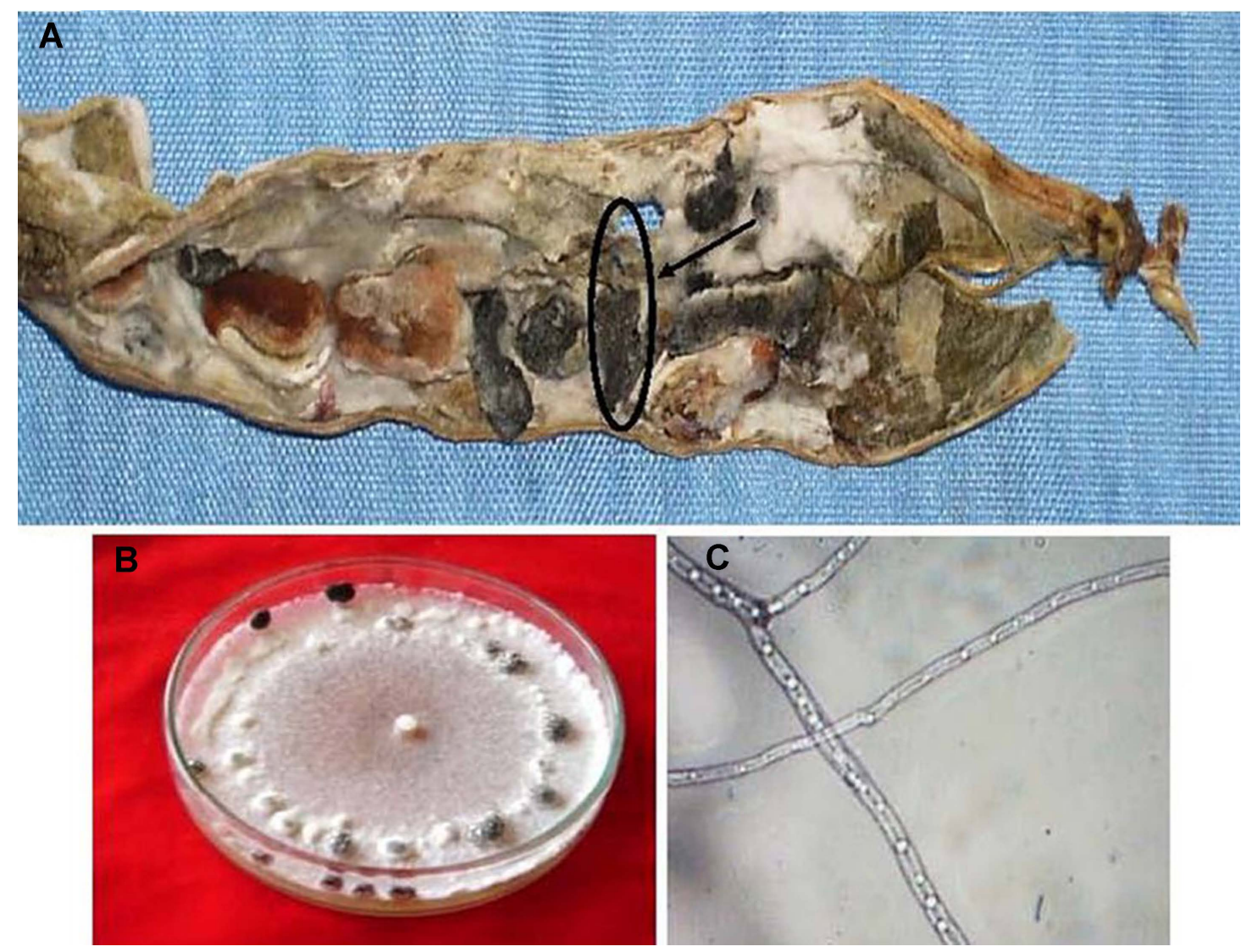

Fig. 1. Field infected hyacinth bean and the isolated fungus. (A) Infected bean pod displaying white mycelium growth and sclerotial development (shown within circles). (B) Pure culture of the infected fungus showing white fluffy mycelium and sclerotial ring. (C) Micrograph of the hyaline mycelium of S. sclerotiorum strain PSHB1. 

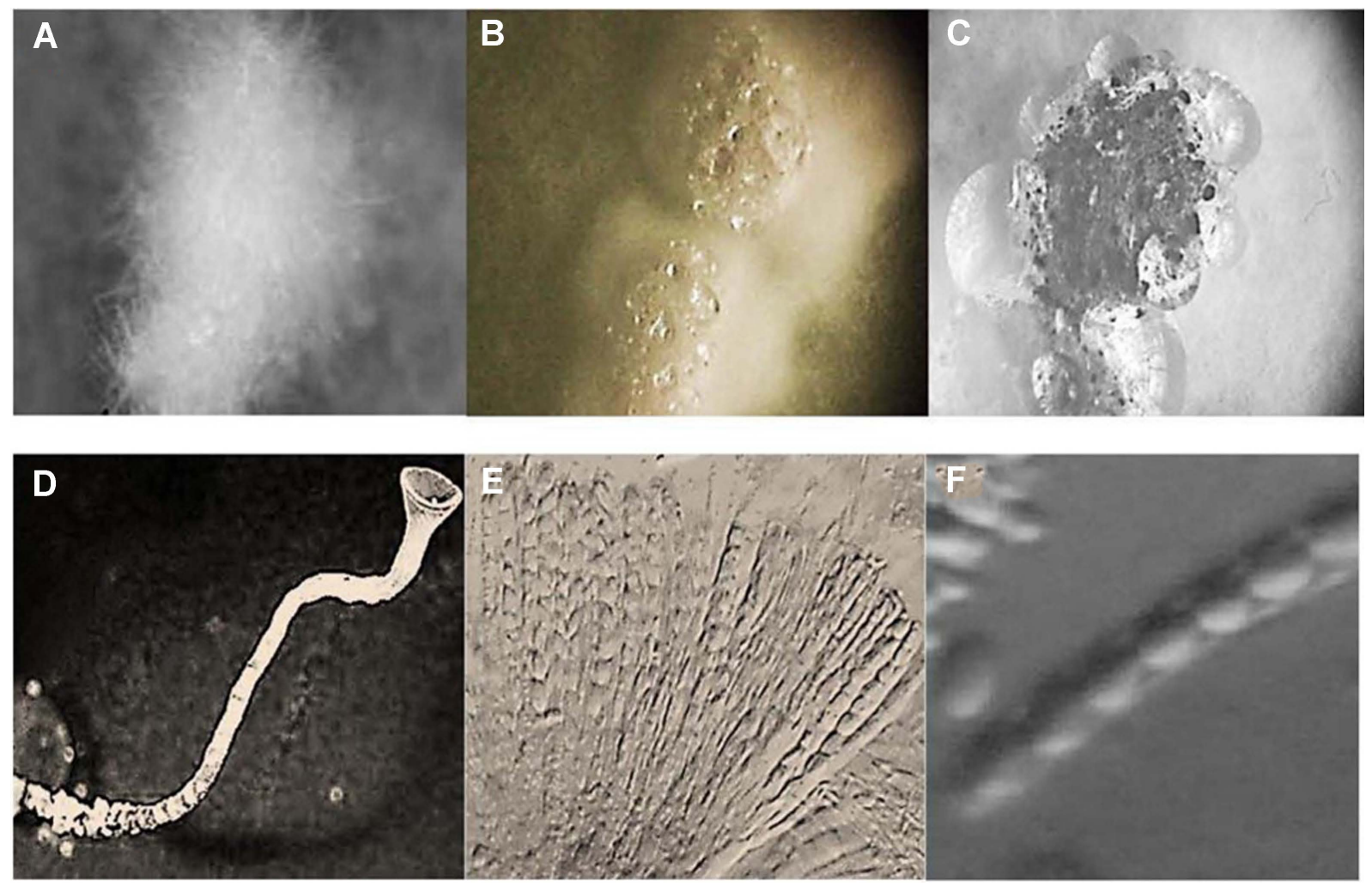

Fig. 2. Photographs showing different stages of sclerotial developments. (A) Initiation stage (5 days after incubation). (B) Development stage (7 days after incubation). (C) Maturation stage (10 days after incubation). (D) Induced formation of matured apothecia. (E) Rows of asci containing ascospores. (F) Ascus with eight ascospores.

Three macroscopically distinct stages were observed during the course of sclerotial development. Sclerotia were white colored at the beginning (initiation), turning beige colored after some days of growing (development) and then black at maturity (maturation) (Fig. 2A-C). Apothecia were produced at 5 to 6 weeks of incubation. Individual to several apothecia arose from a sclerotium and were tan to amber colored. Receptacles were broad, slightly concave when young and convex at maturity often with a central depression (Fig. 2D). Fully mature apothecia were 4-6 $\mathrm{mm}$ in diameter with a stipe length of 3-5 $\mathrm{mm}$. Asci from apothecia were cylindrical and eight-spored (Fig. 2E). Ascospores were uniseriate, single celled, hyaline and ellipsoid (Fig. 2F). Paraphyses were abundant. These characteristics are consistent with those described for Sclerotinia.

Pathogenicity tests. Lesions on the inoculated plants started appearing by $48 \mathrm{~h}$ post-inoculation and all plants had lesions by 4-5 day post-inoculation. Initially test plants began to show symptoms of water-soaked lesions around the point of inoculation. The lesions progressed upward and downward in the stem and formed a distinct demarcation zone between healthy and infected tissue. Ten days after inoculation all plants had already wilted and died and stem breakage were also observed for some dead plants. Dark sclerotia were found after splitting the dead stems of all inoculated plants. Fragments of dead plants developed white mycelia and sclerotia typical of $S$. sclerotiorum when they were kept in a moist chamber. Control plants did not develop any disease symptoms. Pathogenicity testing of the candidate isolate on hyacinth bean pods revealed that symptoms identical to those observed in the farmer's field developed 10-15 days after inoculation. All inoculated pods were successfully infected by the isolate. The inoculated pods were destroyed within 3 weeks. Sclerotia of different sizes and shapes were also formed on and inside the infected pods.

In the cross-inoculation assay all three isolates infected all three inoculated host plants. In all tested plants the same symptoms were observed as described above. Re-isolation of the pathogen was done from symptomatic plant tissues in each of the cases and the colony and fungal morphologies were identical to those recovered from the field in- 
fected plants.

Molecular identification of the pathogen. The ITS sequences obtained in this study were $564 \mathrm{bp}$ in length. Homology search through GenBank DNA database revealed the ITS rDNA sequence of the hyacinth bean isolate shared $100 \%$ sequence identity with that of several $S$. sclerotiorum isolates collected from different vegetable crops (accession nos. KJ744364.1, KX184720.1, KT224645.1, AB233346.1, HQ833450.1, MG249967.1, DQ329537.1, JN013184.1, FJ810516.1, KY750530.1, AB937095.1, KJ614584.1, KF859932.1, KY073612.1, KY073613.1, KY073614.1, KP340898.1). This confirms that the isolated fungus is a member of this group. The candidate sequence was submitted to NCBI GenBank and given an accession no. KF791510. Based on maximum sequence homology percentage, query coverage, and the lowest E value, ITS sequence data of eight isolates of $S$. sclerotiorum were selected for phylogenetic analysis. Additionally, four isolates of each of S. minor, S. trifoliorum and Botryoitinia fuckeliana were included in this analysis, while Hypocrea lixii was used as an out group (GenBank accession no. FJ 861393.1). The obtained sequences were aligned by Clustal-X using MEGA (version 6.0 software), and neighbor joining tree was generated using the same software. In the phylogenetic tree, the fungus isolated from hyacinth bean plants grouped with strains of S. sclerotiorum with good bootstrap support (Fig. 3). The results revealed that isolated fungus is a strain of $S$. sclerotiorum.

Effect of temperature and pH on growth of $S$. sclerotiorum. The growth of $S$. sclerotiorum in response to temperature was not clearly visible until $96 \mathrm{~h}$ after incuba-

\footnotetext{
S. sclerotiorum_AB937095.1

S. sclerotiorum_JN013184.1

S. sclerotiorum_KJ744384.1

S. sclerotiorum_KF859932.1

S. sclerotiorum_DQ329537.1

S. sclerotiorum_HQ833450.1

S. sclerotiorum_KY750530.1

S. sclerotiorum_KY073614.1

S. sclerotiorum_FJ810516.1

S. sclerotiorum_KY073812.1

S. sclerotiorum_KT224645.1

S. sclerotiorum_KP340898.1

S. sclerotiorum_KY073613.1

S. sclerotiorum_AB233346.1

PSHB_1_KF791510.1

S. sclerotiorum_KJ614564.1

S. sclerotiorum_MG249967.1

S. sclerotiorum_KX184720.1

S. trifoliorum_KT224652.1

S. trifoliorum_KT986229.1

S. trifoliorum_KT224651.1

S. trifoliorum_KT819299.1

S. minor_JF279877.1

S. minor_AB516661.1

S. minor_JF279879.1

S. minor_JF279880.1
}

Hypocrea_lixii_FJ881393.1

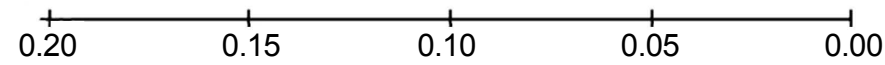

Fig. 3. Tree view of phylogenetic relationship of $S$. sclerotiorum strain PSHB1. Distance tree using neighbor joining method was constructed for 26 clades (21 references and one clone) with bootstrap consensus using MEGA 5. 

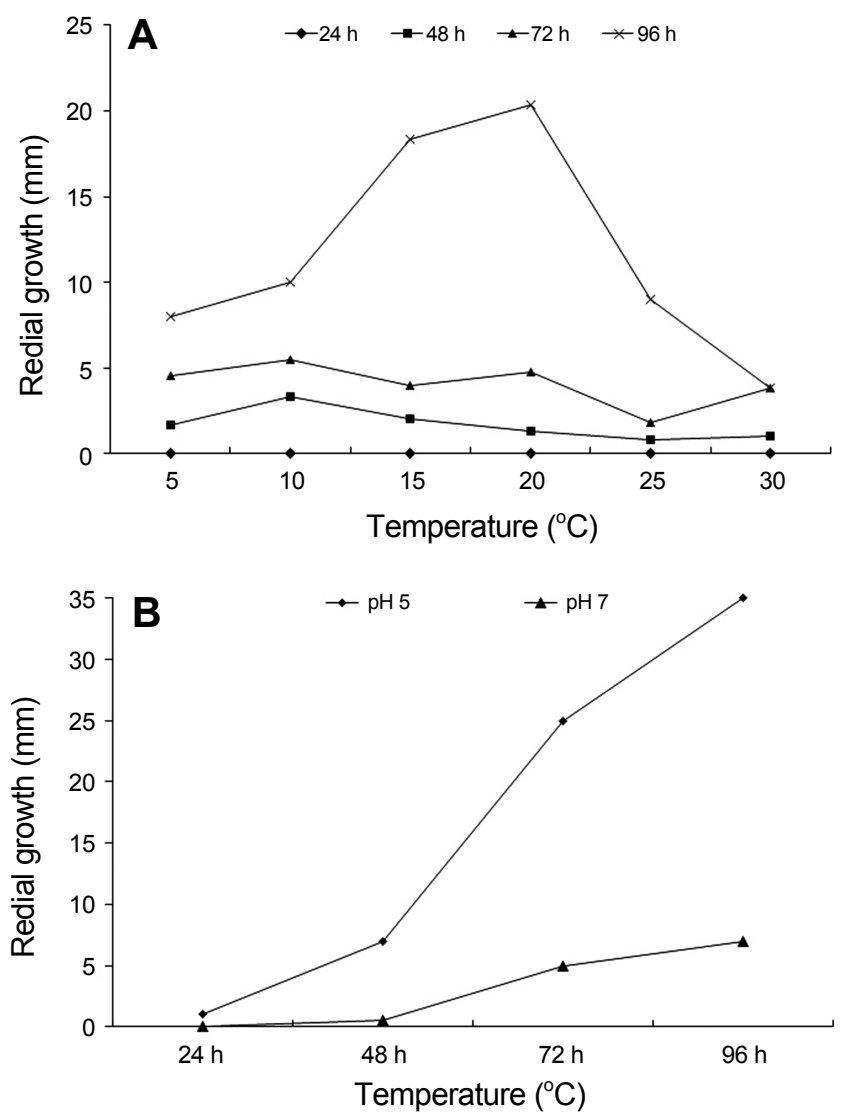

Fig. 4. Radial growth of $S$. sclerotiorum mycelia on PDA at (A) different temperatures and (B) $\mathrm{pH}$.

tion. The fungus could grow at variety of temperature from $5^{\circ} \mathrm{C}$ to $30^{\circ} \mathrm{C}$, although the growth was affected by variation of temperature. At $5^{\circ} \mathrm{C}$ mycelial growth of the isolate was very sparse and as the temperature increased to $10^{\circ} \mathrm{C}$, the growth occurred faster (Fig. 4A). Increasing temperature to $15^{\circ} \mathrm{C}$ resulted in doubling of mycelial growth of the fungus. However, growth was the highest at $20^{\circ} \mathrm{C}$ and as the temperature increased further to 25 and $30^{\circ} \mathrm{C}$, the growth declined (Fig. 4A). We also examined the growth of $S$. sclerotiorum in response to acidic (5.0) and neutral $\mathrm{pH}$ (7.0). The pathogen could tolerate both $\mathrm{pH}$, but good growth was favored at pH 5.0 (Fig. 4B). Similarly, the number of sclerotia formation and their diameter and weight were significantly higher at pH 5.0 than at pH 7.0 (Fig. 5).

Effect of different carbon sources and $\mathrm{pH}$ values on mycelial growth and sclerotial formation of S. sclerotiorum. The carbon sources for optimum mycelial growth of $S$. sclerotiorum were sucrose and mannitol followed by glucose. The radial growth of the fungus ranged from 43.00 to $21.67 \mathrm{~mm}$ in sucrose, 43.00 to $31.67 \mathrm{~mm}$ in mannitol and 39.33 to $25.00 \mathrm{~mm}$ in glucose $96 \mathrm{~h}$ after culture.

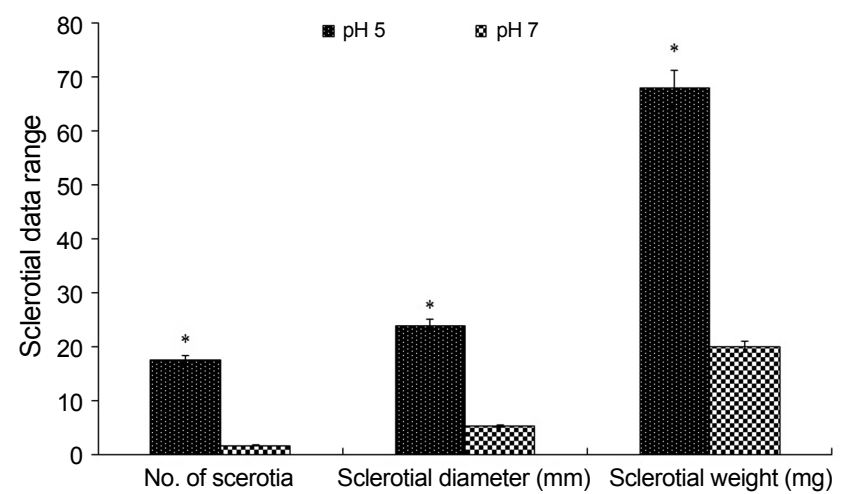

Fig. 5. Graphical presentation showing influence of $\mathrm{pH} 5.0$ and $\mathrm{pH} 7.0$ on sclerotial number, sclerotial diameter $(\mathrm{mm})$ and sclerotial weight $(\mathrm{mg})$. Bars are the Mean $\pm \mathrm{SE}$. *Indicates significant difference by t-test $(P \leq 0.05)$.

Meanwhile, soluble starch supported weak growth having a colony diameter of 4.17 to $1.33 \mathrm{~mm}$ after $96 \mathrm{~h}$ of incubation. In all carbon sources, the highest mycelial growth was observed at acidic $\mathrm{pH}$ (5.0), while increasing of $\mathrm{pH}$ to neutral (pH 7.0) and alkaline (pH 10.0) resulted in slowed mycelial growth. Sclerotial formation was also found to be directly correlated with carbon sources and its $\mathrm{pH}$ level requirements. The highest sclerotial weight (41.67 to 38.00 g) was observed in glucose and the lowest slcerotial weight (11.67 to $0.00 \mathrm{~g}$ ) was observed in starch media. Good sclerotial production was also supported in sucrose and mannitol with a sclerotial weight ranging from 30.33 to $9.67 \mathrm{mg}$ and 20.33 to $11.67 \mathrm{mg}$, respectively. Most optimum $\mathrm{pH}$ for highest sclerotial production was 5.0 in all carbon sources, while sclerotial production decreased with increased $\mathrm{pH}$. In starch, a complete inhibition of sclerotial production was observed at $\mathrm{pH} 7.0$ and 10.0 (Table 2).

Screening of hyacinth bean cultivars. Chlorosis and necrosis due to the infection by the fungus appeared within 4 days after inoculation. No such symptoms were observed in the control. The genotypes widely varied in their response to $S$. sclerotiorum infection. The genotypes HB75, HB-91 (Ira Sheem), HB-98 (BARI Sheem-2), HB-100 (BARI Sheem-4) and HB-101 were highly susceptible (HS) to $S$. sclerotiorum, as the inoculated leaves showed disease severity between 80.0 to $97.44 \%$. Genotypes HB-76 (NMS-2), HB-77 (Jaforer sheem), HB-83 (Green Sheem), HB-90, HB-92 (IPSA-2), and HB-99 (BARI Sheem-3) exhibited disease severity of $55.58-73.50 \%$ and evaluated as susceptible (S). Only one line HB-94 (Ashina) was classified as moderate resistant (MR) as it showed disease severity of $39.89 \%$. Relatively lower values of disease severity ( 15.57 to $20.60 \%$ ) were observed in two genotypes 
Table 1. List of hyacinth bean genotypes screened against S. sclerotiorum strain PSHB1

\begin{tabular}{llll}
\hline Lines & Alternate name & Type of variety & Sources \\
\hline HB-75 & & Local Variety & Siddique Bazar, Dhaka \\
HB-76 & NMS-2 & Hybrid variety & Namdhari Malik Seeds (Pvt.) Ltd. \\
HB-77 & Jaforer Sheem & Local cultivar & Farmer, Kaligong, Jhenidah \\
HB-82 & Rupban Sheem & Hybrid variety & Energypac Agro ltd. \\
HB-83 & Green Sheem & High yielding variety & Bangabandhu Sheikh Mujibur Rahman Agricultural University \\
HB-90 & & Local Variety & Siddique Bazar, Dhaka \\
HB-91 & Ira Sheem & Local Variety & Siddique Bazar, Dhaka \\
HB-92 & IPSA-2 & Inbreed variety & Bangabandhu Sheikh Mujibur Rahman Agricultural University \\
HB-94 & Ashina & Local Variety & Tareq Seed Store,ha Chittagong \\
HB-97 & BARI Sheem-1 & High yielding variety & Bangladesh Agricultural Research Institute \\
HB-98 & BARI Sheem-2 & High yielding variety & Bangladesh Agricultural Research Institute \\
HB-99 & BARI Sheem-3 & High yielding variety & Bangladesh Agricultural Research Institute \\
HB-100 & BARI Sheem-4 & High yielding variety & Bangladesh Agricultural Research Institute \\
HB-101 & & Local Variety & Farmer, Khishorgonj \\
HB-102 & & Local Variety & Farmer, Chittagong Hill Tracts \\
HB-103 & & Local Variety & Farmer, Chittagong Hill Tracts \\
\hline
\end{tabular}

HB-97 (BARI Sheem-1) and HB-103 and were considered resistant (R). Among the sixteen, only two entities HB-82 (Rupban Sheem) and HB-102 showed almost no disease $(0.04$ to $0.01 \%)$ to $S$. sclerotiorum and leveled as highly resistant (HR) (Table 3).

In vitro growth of $S$. sclerotiorum on fungicide and $\mathrm{CaCl}_{2}$-amended agar. Agar amended with each of the six fungicides and $\mathrm{Ca}$ reduced mycelial growth of S. sclerotiorum compared with the growth on non-amended PDA

Table 2. Effect of different carbon sources on radial growth and sclerotial development of $S$. sclerotiorum in hyacinth bean at different $\mathrm{pH}$

\begin{tabular}{lllc}
\hline $\begin{array}{l}\text { Carbon } \\
\text { sources }\end{array}$ & & $\begin{array}{c}\text { Radial mycelial } \\
\text { growth }(\mathrm{mm})^{\mathrm{a}}\end{array}$ & $\begin{array}{c}\text { Sclerotial weight } \\
(\mathrm{mg})^{\mathrm{a}}\end{array}$ \\
\hline \multirow{3}{*}{ Glucose } & $\mathrm{pH}=5$ & $39.33 \pm 0.67 \mathrm{ab}$ & $41.67 \pm 0.33 \mathrm{~b}$ \\
& $\mathrm{pH}=7$ & $32.33 \pm 1.45 \mathrm{bc}$ & $38.33 \pm 0.88 \mathrm{~b}$ \\
& $\mathrm{pH}=10$ & $25.00 \pm 0.00 \mathrm{~b}$ & $38.00 \pm 0.00 \mathrm{~b}$ \\
\hline \multirow{5}{*}{ Sucrose } & $\mathrm{pH}=5$ & $43.00 \pm 1.00 \mathrm{ab}$ & $30.33 \pm 0.88 \mathrm{bc}$ \\
& $\mathrm{pH}=7$ & $42.33 \pm 1.45 \mathrm{ab}$ & $28.00 \pm 1.15 \mathrm{bc}$ \\
& $\mathrm{pH}=10$ & $21.67 \pm 1.67 \mathrm{~b}$ & $9.67 \pm 0.88 \mathrm{~b}$ \\
\hline \multirow{4}{*}{ Mannitol } & $\mathrm{pH}=5$ & $43.00 \pm 1.00 \mathrm{a}$ & $20.67 \pm 0.67 \mathrm{bc}$ \\
& $\mathrm{pH}=7$ & $40.00 \pm 0.00 \mathrm{a}$ & $14.00 \pm 0.58 \mathrm{~b}$ \\
& $\mathrm{pH}=10$ & $31.67 \pm 0.00 \mathrm{~b}$ & $11.67 \pm 0.88 \mathrm{~b}$ \\
\hline \multirow{5}{*}{ Starch } & $\mathrm{pH}=5$ & $4.17 \pm 0.17 \mathrm{bc}$ & $11.33 \pm 0.88 \mathrm{~b}$ \\
& $\mathrm{pH}=7$ & $3.50 \pm 0.00 \mathrm{bc}$ & $0.00 \mathrm{bcd}$ \\
& $\mathrm{pH}=10$ & $1.33 \pm 0.33 \mathrm{~b}$ & $0.00 \mathrm{bcd}$ \\
\hline
\end{tabular}

${ }^{a}$ Values are the Mean \pm SE. Mean values in each column with the same letter(s) do not differ significantly by LSD $(P \leq 0.05)$.
(Table 4). The level of mycelial growth inhibition depended on the concentration of fungicides or chemicals

Table 3. Disease severity of highly susceptible (HS), susceptible (S), moderately resistant (MR), resistant (R) and highly resistant (HR) hyacinth bean genotypes during infection by S. sclerotiorum strain PSHB1

\begin{tabular}{lcc}
\hline Hyacinth bean genotypes & $\begin{array}{c}\text { Disease severity } \\
(\%)^{\mathrm{a}}\end{array}$ & $\begin{array}{c}\text { Types of } \\
\text { resistance* }\end{array}$ \\
\hline HB-75 & $92.94 \pm 2.88 \mathrm{ab}$ & $\mathrm{HS}$ \\
HB-76 (NMS-2) & $72.64 \pm 1.67 \mathrm{~cd}$ & $\mathrm{~S}$ \\
HB-77 (Jaforer Sheem) & $55.58 \pm 0.67 \mathrm{e}$ & $\mathrm{S}$ \\
HB-82 (Rupban Sheem) & $0.00 \pm 0 \mathrm{~g}$ & $\mathrm{HR}$ \\
HB-83 (Green Sheem) & $63.91 \pm 0 \mathrm{de}$ & $\mathrm{S}$ \\
HB-90 & $56.83 \pm 1.67 \mathrm{e}$ & $\mathrm{S}$ \\
HB-91(Ira Sheem) & $97.44 \pm 1.67 \mathrm{a}$ & $\mathrm{HS}$ \\
HB-92 (IPSA-2) & $57.54 \pm 0.67 \mathrm{e}$ & $\mathrm{S}$ \\
HB-94 (Ashina) & $39.89 \pm 1.67 \mathrm{f}$ & $\mathrm{MR}$ \\
HB-97 (BARI Sheem-1) & $15.57 \pm 0 \mathrm{~g}$ & $\mathrm{R}$ \\
HB-98 (BARI Sheem-2) & $90.00 \pm 2.89 \mathrm{ab}$ & $\mathrm{HS}$ \\
HB-99 (BARI Sheem-3) & $73.50 \pm 0 \mathrm{~cd}$ & $\mathrm{~S}$ \\
HB-100 (BARI Sheem-4) & $94.00 \pm 0.67 \mathrm{a}$ & $\mathrm{HS}$ \\
HB-101 & $80.00 \pm 2.89 \mathrm{bc}$ & $\mathrm{HS}$ \\
HB-102 & $0.00 \pm 0 \mathrm{~g}$ & $\mathrm{HR}$ \\
HB-103 & $20.60 \pm 0.67 \mathrm{f}$ & $\mathrm{R}$ \\
\hline
\end{tabular}

*Types of resistance: Disease severity, $\mathrm{HS} \geq 75.0 \%, \mathrm{~S} \geq(50.0-74.9 \%)$, $\mathrm{MR} \geq(25.0-49.9 \%), \mathrm{R} \geq(1.0-25.0 \%)$ and $\mathrm{HR} \geq(0.0-0.99 \%)$. HSHighly Susceptible, S-Susceptible, MR-Moderately Resistant, RResistant, HR- Highly Resistant. ${ }^{a}$ Values are the Mean \pm SE. Mean values in each column with the same letter(s) do not differ significantly by $\operatorname{LSD}(P \leq 0.05)$. 
Table 4. In vitro performance of different concentrations of fungicides and calcium $\left(\mathrm{CaCl}_{2}\right)$ in mycelial growth inhibition of $S$. sclerotiorum strain PSHB1

\begin{tabular}{|c|c|c|}
\hline Treatments & $\begin{array}{c}\text { Concentrations } \\
\text { (ppm) }\end{array}$ & $\begin{array}{l}\% \text { Inhibition of } \\
\text { mycelial growth of } \\
\text { S. sclerotiorum }\end{array}$ \\
\hline \multirow{3}{*}{ Metalaxyl-M } & 10 & $8.15 \pm 0.46 \mathrm{~m}$ \\
\hline & 50 & $86.60 \pm 1.67 c$ \\
\hline & 100 & $94.06 \pm 1.15 b$ \\
\hline \multirow{3}{*}{ Bavistin 50\% WP } & 10 & $28.15 \pm 2.76 \mathrm{jk}$ \\
\hline & 50 & $99.26 \pm 0.27 \mathrm{a}$ \\
\hline & 100 & $100.00 \pm 0.00 \mathrm{a}$ \\
\hline \multirow{3}{*}{ Ridomil-G } & 10 & $20.00 \pm 1.15 \mathrm{kl}$ \\
\hline & 50 & $22.22 \pm 1.43 \mathrm{k}$ \\
\hline & 100 & $80.73 \pm 2.12 d$ \\
\hline \multirow{3}{*}{ Dithane M-45 } & 10 & $77.78 \pm 0.98 \mathrm{e}$ \\
\hline & 50 & $100.00 \pm 0.00 \mathrm{a}$ \\
\hline & 100 & $100.00 \pm 0.00 \mathrm{a}$ \\
\hline \multirow{3}{*}{ Rovral $^{\circledR}$} & 10 & $33.33 \pm 1.68 j$ \\
\hline & 50 & $59.33 \pm 0.94 h$ \\
\hline & 100 & $100.00 \pm 0.00 \mathrm{a}$ \\
\hline \multirow{3}{*}{ Kumulus $^{\circledR}$} & 10 & $51.84 \pm 2.24 \mathrm{i}$ \\
\hline & 50 & $66.67 \pm 0.96 \mathrm{~g}$ \\
\hline & 100 & $71.11 \pm 0.68 \mathrm{f}$ \\
\hline \multirow{3}{*}{ Calcium $\left(\mathrm{CaCl}_{2}\right)$} & 0.062 & $94.80 \pm 0.17 b$ \\
\hline & 0.125 & $99.71 \pm 0.03 \mathrm{a}$ \\
\hline & 0.25 & $99.87 \pm 0.01 \mathrm{a}$ \\
\hline Control & 0.00 & $0.00 \pm 0.00$ \\
\hline
\end{tabular}

${ }^{a}$ Values represent mean $\pm \mathrm{SE}(n=4)$; one replication consists of three plates. Within each column, different letters indicate a statistically significant difference between treatments (Fisher's LSD, $P \leq 0.05$ ). The experiment was conducted twice. Significant treatment effects were identical in the two trials. Data shown are from one trial.

in the PDA. Dithane M-45 was found to be most effective fungicide that completely retarded the mycelial growth of S. sclerotiorum, at $100 \mathrm{ppm}$ and $50 \mathrm{ppm}$ of PDA (Table 4). Rovral was only effective at $100 \mathrm{ppm}$, showing $100 \%$ inhibition of mycelial growth. Bavistin WP completely inhibited the mycelial growth of S. sclerotiorum at $100 \mathrm{ppm}$, while $99.26 \%$ inhibition was recorded at $50 \mathrm{ppm}$. Metalaxyl-M inhibited mycelial growth 86.60 and $96.06 \%$ at 50 and 100 ppm of agar, respectively. Ca in the form of $\mathrm{CaCl}_{2}$ was also highly suppressive against mycelial growth of $S$. sclerotiorum, as it reduced mycelial growth $99.71 \%$ and $99.87 \%$ at $0.13 \mathrm{~g}$ and $0.25 \mathrm{~g} \mathrm{Ca} / \mathrm{ml}$ of PDA, respectively. On the contrary, Ridomil-G and Kumulus were least inhibitory against $S$. sclerotiorum and found to reduce mycelial growth by $80.73 \%$ and $71.11 \%$, respectively at $100 \mathrm{ppm}$ of agar.

\section{Discussion}

This study detects and characterizes the Sclerotinia infection in hyacinth bean field in Bangladesh. The disease was observed in bean field in successive years since 2012, with a significant lower yield. According to our observations, this fungus produces a range of unique characteristic symptoms that are not exhibited by other diseases in hyacinth bean crop, such as anthracnose or rust (Bashir and Malik, 1988). One fungus was consistently isolated from symptomatic tissues of hyacinth bean plants. The presence of cottony mycelium and large black sclerotia on, in and around infected plants must be evidences in supporting the pathogenicity establishment of S. sclerotiorum (Kirk et al., 2001). Under the microscope we observed that hyphae were hyaline, branched and multinucleated. These characters are in accordance with those reported for the fungal species S. sclerotiorum (Kohn, 1979). After inoculation with the pathogen, test plants began to present symptoms typical of $S$. sclerotiorum and similar to those observed in the field. The cross-infection of three host plants with three isolates of different host origin is in accordance with other authors, who have reported the wide host range of this pathogen and its lack of host specificity (Mendes et al., 1998; Reis et al., 2007). The wide host range of the pathogen has epidemiological implications and makes the management of white mold very difficult, especially in terms of crop rotation (Reis et al., 2007).

The morphological and symptom characteristics may provide clues for accurate identification of $S$. sclerotiorum. The role of ascospores is important in initiating foliar infections on crops such as beans and canola (Bolton et al., 2005; McDonald and Boland, 2004; Sanogo and Puppala, 2007) and could be involved in initiating infections on hyacinth bean. No ascocarps were detected in hyacinth bean field at the time of the survey. However, in vitro conditions induced sclerotia to germinate carpogenically to produce one or more stipes with apothecia. The asci and ascospores that appeared in the apothecia were very similar to those of previously reported S. sclerotiorum (Sanogo and Puppala, 2007). Numerous studies have already demonstrated that the importance of comparative sequencebased strategies for fungal species identification in addition to morphological characteristics (Summerbell et al., 2007). However, the success of a comparative sequencing strategy for the identification of a fungus lies mainly in the choice of the appropriate locus. Multiple studies have confirmed the effectiveness of the nuclear ribosomal 
internal transcribed spacer (ITS) region (ITS1, 5.8S rRNA, and ITS2) sequences located between the nuclear smalland large-subunit rRNA genes for species complexlevel identification (Hossain et al., 2014; Mahmoud and Zaher, 2015). The data presented here demonstrate that PCR amplification of the ITS gene fragment using specifically designed primer pair, followed by sequencing and phylogenetic analysis identified the isolate as $S$. sclerotiorum. In addition, Koch's postulates demonstrated the pathogenicity of this fungus and its role as the causal agent of the new disease detected in Bangladesh. S. sclerotiorum has been reported to be the pathogen of white mold disease of hyacinth bean in other countries (Harveson et al., 2010; Saharan and Mehta, 2008). The fungus causes flower blights, stem rots, fruit rots, head blight, crown rots and basal stem infection of numerous hosts (Heffer and Johnson, 2007). This species has a large distribution in many countries (Bolton et al., 2005). In Bangladesh, $S$. sclerotiorum was previously reported on hyacinth bean, marigold, jackfruit and okra (Prova et al., 2012, 2014, 2017; Rahman et al., 2015). The pathogen has potential to spread to other host species.

The detailed characterization of S. sclerotiorum and its biology is necessary for determining the appropriate management strategies. Manifestation of Sclerotinia disease is highly dependent on environmental factors (Sanogo and Puppala, 2007). The present study indicates that highest mycelial growth of $S$. sclerotiorum was achieved at $20^{\circ} \mathrm{C}$, while the growth was reduced at 25 and $30^{\circ} \mathrm{C}$. Similar best growth of $S$. sclerotiorum was also previously observed between 19 to $20^{\circ} \mathrm{C}$ (Sanogo and Puppala, 2007). It suggests that cooler temperatures may contribute to the better growth of the fungus and subsequently to initiation of the disease (Phipps, 1995). Additionally, $\mathrm{pH}$ has been implicated as a primary regulatory factor for processes linked to pathogenicity, development, and virulence of $S$. sclerotiorum (Rollins and Dickman, 2001). The present study shows that the hyacinth bean isolate of $S$. sclerotiorum had substantially greater growth and sclerotial yield at $\mathrm{pH} 5.0$ than at $\mathrm{pH}$ 7.0 and 10.0. Similarly, this study confirmed that mycelial growth and sclerotial development in $S$. sclerotiorum have an important relationship with the metabolism of different carbon sources. Mannitol and sucrose appeared to support the highest hyphal growth of the fungus, while soluble starch rich was responsible for the least growth of the fungus. On the contrary, glucose gave the highest sclerotial weight, while the lowest sclerotial weight was observed in starch media. This specifies that the condition favoring the mycelial growth would not necessarily coincide with that favoring sclerotial development. The data in this study also indicated that mycelial growth and sclerotial formation became higher in these four carbon source media only when the $\mathrm{pH}$ was acidic. It is well documented that oxalic acid accumulation lowers the ambient $\mathrm{pH}$ and favors the sclerotial development in S. sclerotiorum, whereas neutral or alkaline $\mathrm{pH}$ discourages them (Cuong and Dohroo, 2006). This indicates existence of a complex mechanism in fungal morphogenesis which is under great influence of $\mathrm{pH}$ (Xing et al., 2011).

Information on differences in susceptibility in hyacinth bean is currently lacking. The genotypes widely varied in their response to $S$. sclerotiorum infection. Majority (68.75\%) of the hyacinth bean genotypes were susceptible to highly susceptible. A few cultivars were also resistant to moderately resistant in this test. Among hyacinth genotypes, HB-82 (Rupban Sheem) and HB102 were found highly resistant to the fungus. Based upon the available level of resistance, it is advocated that the identified genotypes could be utilized as sources of germplasm for incorporating resistance against Sclerotinia infection.

In practice, the application of fungicides is the principal response in most crops for managing Sclerotinia stem rot. However, the sensitivity of $S$. sclerotiorum isolates to fungicides in Bangladesh is currently unknown. Thus, it is essential to investigate fungicidal sensitivity in $S$. sclerotiorum isolates from hyacinth bean in order to assess the effectiveness of fungicides. We screened the commonly available fungicides. Our data indicate the sufficient efficiency of Dithane M-45 (mancozeb), Bavistin 50\% WP (carbendazim), Rovral (iprodione) and Ca (in the form of $\mathrm{CaCl}_{2}$ ) as compared with the others when used to control S. sclerotiorum. The fungicidal potentials of carbendazim, mancozeb and iprodione were reported against $S$. sclerotiorum in previous studies (Mueller et al., 2004; Singh et al., 2014; Wang et al., 2014). Similarly, Wilson et al. (2005) reported that $\mathrm{Ca}$ in the form of $\mathrm{Ca}(\mathrm{OH})_{2}$ inhibited $S$. minor's sclerotial germination and infection at the collar region of lettuce plants. Similarly, $\mathrm{CaCl}_{2}$ at $300 \mathrm{ppm}$ concentration in the medium completely inhibited the growth of mycelium and decreased the germination of spores of Botrytis cinerea (Boumaaza et al., 2015). Calcium was effective in inhibiting spore germination of Colletotrichum gloeosporioides (Biggs, 1999), Rhizopus stolonifera (Tian et al., 2002), and Alternaria alternata and Penicillium expansum (Maouni et al., 2007). The mechanisms by which calcium salts inhibit the development and severity of diseases has not been known yet. One hypothesis is that high external $\mathrm{Ca}^{2+}$ 
concentrations may increase the concentration of $\mathrm{Ca}^{2+}$ in the cytosol, which can be toxic to the fungus.

Combined results of morphological, molecular and pathological analyses identified the fungus isolated from naturally infected hyacinth bean plants as $S$. sclerotiorum (Lib) de Bary. Although the potential of S. sclerotiorum to become a pathogen was widely demonstrated on Phaseolus bean (Tu, 1997), very limited information is known on hyacinth bean. Therefore, the present study is the first evidence of hyacinth bean infection in the field in Bangladesh, extending the host range of $S$. sclerotiorum. This report contributes to more information about the epidemiology of the disease and can be useful in implementing effective management strategies for the disease.

\section{Conflict of Interest}

The authors declare that they have no conflict of interest.

\section{Acknowledgements}

The authors would like to acknowledge the financial assistance from the Ministry of Science and Information and Communication Technology (MOSICT), Project No. 41/1(7), Government of the People's Republic of Bangladesh.

\section{References}

Akhter, W., Bhuiyan, M. K., Sultana, F. and Hossain, M. M. 2015. Integrated effect of microbial antagonist, organic amendment and fungicide in controlling seedling mortality (Rhizoctonia solani) and improving yield in pea (Pisum sativum L.). C. R. Biol. 338:21-28.

Amselem, J., Cuomo, C. A., van Kan, J. A. L., Viaud, M., Benito, E. P., Couloux, A., Coutinho, P. M., de Vries, R. P., Dyer, P. S., Fillinger, S., Fournier, E., Gout, L., Hahn, M., Kohn, L., Lapalu, N., Plummer, K. M., Pradier, J. M., Quévillon, E., Sharon, A., Simon, A., ten Have, A., Tudzynski, B., Tudzynski, P., Wincker, P., Andrew, M., Anthouard, V., Beever, R. E., Beffa, R., Benoit, I., Bouzid, O., Brault, B., Chen, Z., Choquer, M., Collémare, J., Cotton, P., Danchin, E. G., Da Silva, C., Gautier, A., Giraud, C., Giraud, T., Gonzalez, C., Grossetete, S., Güldener, U., Henrissat, B., Howlett, B. J., Kodira, C., Kretschmer, M., Lappartient, A., Leroch, M., Levis, C., Mauceli, E., Neuvéglise, C., Oeser, B., Pearson, M., Poulain, J., Poussereau, N., Quesneville, H., Rascle, C., Schumacher, J., Ségurens, B., Sexton, A., Silva, E., Sirven, C., Soanes, D. M., Talbot, N. J., Templeton, M., Yandava, C., Yarden, O., Zeng, Q., Rollins, J. A., Lebrun, M. H. and Dickman, M. 2011. Genomic analysis of the necrotrophic fungal pathogens Sclerotinia sclerotiorum and
Botrytis cinerea. PLoS Genet. 7:e1002230.

Bardin, S. D. and Huang, H. C. 2001. Research on biology and control of Sclerotinia diseases in Canada. Can. J. Plant Pathol. 23:88-98.

Bashir, M. and Malik, B. A. 1988. Diseases of major pulse crops in Pakistan-a review. Trop. Pest Manag. 34:309-314.

Boumaaza, B., Benkhelifa, M. and Belkhoudja, M. 2015. Effects of two salts compounds on mycelial growth, sporulation, and spore germination of six isolates of Botrytis cinerea in the western north of Algeria. Int. J. Microbiol. 2015:572626.

Bangladesh Bureau of Statistics. 2014. Year Book of Agricultural Statistics - 2014. 26th series. Bangladesh Bureau of Statistics, Ministry of Planning, Government of the People's Republic of Bangladesh, Dhaka, Bangladesh. 405 pp.

Biggs, A. R. 1999. Effects of calcium salts on apple bitter rot caused by two Colletotrichum spp. Plant Dis. 83:1001-1005.

Bolton, M. D., Thomma, B. P. and Nelson, B. D. 2005. Sclerotinia sclerotiorum (Lib.) de Bary: Biology and molecular traits of a cosmopolitan pathogen. Mol. Plant Pathol. 7:1-16.

Chardonnet, C. O., Sams, C. E. and Conway, W. S. 1999. Calcium effect on the mycelial cell walls of Botrytis cinerea. Phytochemistry 52:967-973.

Cuong, N. D. and Dohroo, N. P. 2006. Morphological, cultural and physiological studies on Sclerotinia sclerotiorum, causing stalk rot of cauliflower. Omonrice 14:71-77.

Dong, X., Ji, R., Guo, X., Foster, S. J., Chen, H., Dong, C., Liu, Y., $\mathrm{Hu}, \mathrm{Q}$. and Liu, S. 2008. Expressing a gene encoding wheat oxalate oxidase enhances resistance to Sclerotinia sclerotiorum in oilseed rape (Brassica napus). Planta 228:331-340.

Hatcher, P. E. and Paul, N. D. 2001. Plant-pathogen-herbivore interactions and their effects on weeds. In: Biotic Interactions in Plant-Pathogen Associations, eds. by M. J. Jeger and N. J. Spence, pp. 193-225. CABI Publishing, Wallingford, UK.

Harveson, R. M., Steadman, J. R. and Urrea, C. A. 2010. Integrating planting dates and fungicide applications for managing white mold of dry beans in western Nebraska. Online. Plant Health Prog. doi:10.1094/PHP-2010-0701-02-RS.

Hayakawa, T., Toda, T., Ping, Q., Mghalu, J. M., Yaguchi, S. and Hyakumachi, M. 2006. A new subgroup of Rhizoctonia AGD, AG-D III, obtained from Japanese zoysia grass exhibiting symptoms of a new disease. Plant Dis. 90:1389-1394.

Heffer, L. V. and Johnson, K. B. 2007. White Mold. The Plant Health Instructor. doi: 10.1094/PHI-I-2007-0809-01.

Hossain, M. M., Sultana, F., Miyazawa, M. and Hyakumachi, M. 2014. Plant growth-promoting fungus Penicillium spp. GP 15-1 enhances growth and confers protection against damping-off and anthracnose in the cucumber. J. Oleo Sci. 63:391400.

Huang, H. C., Erickson, R. S., Van Hezewijk, B. and De ClerckFloate, R. 2005. White mold of Houndstongue (Cynoglossum officinale) caused by Sclerotinia sclerotiorum in Canada. Plant Dis. 89:1013.

Islam, S., Akanda, A. M., Prova, A., Islam, M. T. and Hossain, M. M. 2016. Isolation and identification of plant growth 
promoting rhizobacteria from cucumber rhizosphere and their effect on plant growth promotion and disease suppression. Front. Microbiol. 6:1360.

Kirk, P. M., Cannon, P., David, J. and Stalpers, J. 2001. Ainsworth and Bisby's Dictionary of the Fungi. 9th ed. CABI Publishing, Wallingford, UK. 655 pp.

Kohn, L. M. 1979. A monographic revision of the genus Sclerotinia. Mycotaxon 9:365-444.

Mahmoud, A. G. Y. and Zaher, E. H. F. 2015. Why nuclear ribosomal internal transcribed spacer (ITS) has been selected as the DNA barcode for fungi? Adv. Genet. Eng. 4:119.

Maouni, A., Lamarti, A., Aidoun, A., Khaddor, M. and Badoc, A. 2007. Effect of benzimidazole fungicides and calcium chloride on Alternaria alternata and Penicillium expansum rot during storage of pears. Afr. J. Biotechnol. 6:1289-1292.

McDonald, M. R. and Boland, G. J. 2004. Forecasting diseases caused by Sclerotinia spp. in eastern Canada: fact or fiction? Can. J. Plant Pathol. 26:480-488.

Mendes, M. A. S., da Silva, V. L., Dianese, J. C., Ferreira, M. A. S. V., dos Santos, C. E. N., Gomes Neto, E., Urben, A. F. and Castro, C. 1998. Fungos em Plantas no Brasil. 1st ed. Embrapa, Brasília, Brasil. 569 pp.

Mueller, D. S., Bradley, C., Grau, C. R., Gaska, J., Kurle, J. E. and Pedersen, W. L. 2004. Application of thiophanate-methyl at different host growth stages for management of Sclerotinia stem rot in soybean. Crop Prot. 23:983-988.

National Research Council. 2006. Lablab. In: Lost Crops of Africa Volume II: Vegetables, pp. 190-205. The National Academies Press, Washington DC, USA.

Oliver, R. P. and Solomon, P. S. 2010. New developments in pathogenicity and virulence of necrotrophs. Curr. Opin. Plant Biol. 13:415-419.

Prajapati, C. R. and Narain, U. 2008. Effect of fungicides and neem formulations on management of Sclerotinia rot of dolichos bean (Dolichos lablab L.). Agric. Sci. Digest 28:133135.

Prova, A. 2012. Isolation, identification and characterization of white mold disease in marigold (Tagetes officinales L.) and hyacinth bean (Lablab purpureus) caused by Sclerotinia sclerotiorum. M.S. thesis. Bangabandhu Sheikh Mujibur Rahman Agricultural University, Gazipur, Bangladesh.

Prova, A., Akanda, M. A. M., Islam, S., Sultana, F., Islam, M. T., and Hossain, M. M. 2014. First report of stem and pod blight of hyacinth bean caused by Sclerotinia sclerotiorum. J. Plant Pathol. 96:603-611.

Prova, A., Akanda, M. A. M., Islam, S. and Hossain, M. M. 2017. First report of Sclerotinia sclerotiorum cusing pod rot disease on okra in Bangladesh. Can. J. Plant Pathol. 39:72-76.

Phipps, P. M. 1995. An algorithm for prediction outbreaks of Sclerotinia blight of peanut and improving the efficacy of fungicide sprays. Proc. Am. Peanut Res. Educ. Soc. 27:23.

Rahman, M. M. E., Dey, T. K., Hossain, D. M., Nonaka, M. and Harada, N. 2015. First report of white mold caused by Sclerotinia sclerotiorum on jackfruit. Aust. Plant Dis. Notes
$10: 10$.

Reis, A., Costa, H. and Lopes, C. A. 2007. Epidemiologia e manejo do mofo-branco em hortaliças. DF: Embrapa Hortaliças, Brasília, Brasil. 5 pp.

Rollins, J. A. and Dickman, M. B. 2001. pH signaling in Sclerotinia sclerotiorum: Identification of a pacC/RIM1 homolog. Appl. Environ. Microbiol. 67:75-81.

Saharan, G. S and Mehta, N. 2008. Sclerotinia diseases of crop plants: Biology, ecology and disease management. Springer, Dordrecht, Netherlands. 486 pp.

Sanogo, S. and Puppala, N. 2007. Characterization of darkly pigmented mycelium isolate of Sclerotinia sclerotiorum on valencia peanut in New Mexico. Plant Disease 91:1077-1082.

Schwartz, H. F. and Pastor Corrales, M. A. 1989. Bean production problems in the tropics. 2nd ed. Centro Internacional de Agricultura Tropical, Colombia. 726 pp.

Shin, H. J., Kim, C. J. and Kim, S. B. 2007. Optimization of culture medium for rifamycin SV production by Amycolatopsis mediterranei MM2 using statistical designs. Biotechnol. Bioproc. E. 12:457-461.

Singh, N. K., Singh, R. B. and Singh, V. 2014. Efficacy of fungicides and bio-pesticide against the Sclerotinia sclerotiorum causing Sclerotinia rot of Mustard. IOSR-JAVS. 7:20-23.

Summerbell, R. C., Moore, M. K., Starink-Willemse, M. and Van Iperen, A. 2007. ITS barcodes for Trichophyton tonsurans and T. equinum. Med. Mycol. 45:193-200.

Sundar, A. R., Das, N. D. and Krishnaveni, D. 1995. In-vitro antagonism of Trichoderma spp. against two fungal pathogens of Castor. Indian J. Plant Prot. 23:152-155.

Tian, S. P., Fan, Q., Xu, Y. and Jiang, A. L. 2002. Effects of calcium chloride on biocontrol activity of yeast antagonists against the postharvest fungal pathogen Rizopus stolonifer. Plant Pathol. 51:352-358.

Toda, T., Hyakumachi, M., Suga, H., Kageyama, K., Tanaka, A. and Tani, T. 1999. Differentiation of Rhizoctonia AG-D isolates from turfgrass into subgroups I and II based on rDNA and RAPD analysis. Eur. J. Plant Pathol. 105:835-846.

Tu, J. C. 1997. An integrated control of white mold Sclerotinia sclerotiorum (Lib.) de Bary of beans with emphasis on recent advances in biological control. Bot. Bull. Acad. Sin. 38:73-76.

Wang, Y., Duan, Y. B. and Zhou, M. G. 2014. Control of Sclerotinia sclerotiorum infection in oilseed rape with strobilurin fungicide SYP-7017. Can. J. Plant Pathol. 36:354-359.

White, T. J., Bruns, T. D., Lee, S. B. and Taylor, J. W. 1990. Amplification and direct sequencing of fungal ribosomal RNA genes for phylogenetics. In: PCR Protocols: A Guide to Methods and Applications, eds. by M. A. Innis, D. H. Gelfand, J. J. Sninsky and T. J. White, pp. 315-322. Academic Press, New York, USA.

Wilson, C. R., DeLittle, J. A., Wong, J. A. L., Schupp, P. J. and Gibson, L. J. 2005. Adjustment of soil-surface $\mathrm{pH}$ and comparison with conventional fungicide treatments for control of lettuce drop (Sclerotinia minor). Plant Pathol. 54:393-400. 
Williams, B., Kabbage, M., Kim, H. J., Britt, R. and Dickman, M. B. 2011. Tipping the balance: Sclerotinia sclerotiorum secreted oxalic acid suppresses host defenses by manipulating the host redox environment. PLoS Pathog. 7:e1002107.

Woodward, J. E., Baughman, T. A., Baring, M. R. and Simpson, C. E. 2015. Comparison of three high-oleic peanut cultivars under varying field conditions in the Southwestern United States. Peanut Sci. 42:11-17.

Xing, Y. M., Chen, J., Lv, Y. L., Liang, H. Q. and Guo, S. X. 2011. Determination of optimal carbon source and $\mathrm{pH}$ value for sclerotial formation of Polyporus umbellatus under artificial conditions. Mycol. Prog. 10:121-125.

Young, C. S., Smith, J. A., Watling, M., Clarkson, J. P. and Whipps, J. M. 2001. Environmental conditions influencing apothecial production and lettuce infection by Sclerotinia sclerotiorum in field conditions. In: Proceedings of Sclerotinia 2001-the Xl International Sclerotinia Workshop, eds. by C. S. Young and K. J. D. Hughes, pp. 181-182. Central Science Laboratory, York, UK. 